\title{
Investigation of Pedagogical Formation Certification Program Students' Attitudes Towards Teaching Profession in Terms Of Some Variables
}

\author{
Zeynep DEMIRTAŞ ${ }^{1}$ Gökçe Pınar AKSOY²
}

\section{ARTICLE INFO}

\section{Article History:}

Received 20.10.2015

Received in revised form

12.11.2015

Accepted 30.10.2015

Available online 01.01.2016

\begin{abstract}
The aim of the current study is to determine the attitudes of students who have training on pedagogical formation in order to be assigned as a teacher towards teaching profession. Within the scope of this general aim the following question is sought an answer: Do pedagogical formation certification program students' attitudes towards teaching profession change significantly in terms of (1) gender, (2) level of education (grade or graduation) (3) department (studying or graduated), (4) faculty/ high school (studying or graduated) variables? The present study has the characteristics of descriptive survey model. The participants include 644 students who take pedagogical formation at 2010- 2011 Academic year Spring term at Sakarya University's Faculty of Education and who are studying at or graduated from Faculty of Arts and Sciences, Faculty of Fine Arts, Faculty of Theology, School of Physical Education and Sports, Health High School, and School of State Conservatory. Attitude Scale towards Teaching Profession (ASTP), developed by Üstüner (2006), is used as a data collection tool. In order to determine whether total scores obtained from data collection tools differ in terms of variables or not T test, analysis of variance, Mann Whitney U Test and Kruskal Wallis H-test are conducted. According to results, the attitudes of students, taking pedagogical formation, towards teaching profession show significant differences in the sense of faculty/ high school variable and do not show a significant difference with regard to gender and level of education variables. Moreover, attitude scores of students differ in accordance with Faculty of Arts and Sciences and Health High School and do not differ with regards to other departments in other faculties or high schools.
\end{abstract}

(C) 2016 IJERE. All rights reserved

Keywords:

Teaching Profession, Pedagogical Formation, Attitude.

\section{INTRODUCTION}

Teaching is a specific profession responsible for educating the new generations according to the demands of the time. The teaching profession requires perceptual qualifications such as attitudes and behaviours, besides cognitive qualifications such as knowledge and skills. Preparation for teaching profession is assured through liberal education, education for specific field, and pedagogic training. For prospective teachers, acquiring certain values and attitudes related to the profession is as necessary as acquiring knowledge. Besides, for the teachers to have positive attitudes towards the profession, it is important to for prospective teachers, who undergo training on field knowledge, knowledge for teaching profession, and liberal education; to be conscious about sympathy for profession, sincere attachment to the profession, internalization of the importance of the profession for the society, and continuously educating oneself in accordance with the demands of the time (Helvacı, 2007; Celep, 2010; Çelik, 2010).

For the qualifications regarding teaching profession to be gained, and for the positive attitudes to be acquired, the process of being prepared for teaching profession should be sufficient.

In Turkey, graduates of the faculties and academies that provide teaching education and that are affiliated with The Council of Higher Education, are assigned as teachers since 1982. Occasionally, in order to fulfill the need for teachers, people graduated from various institutions that provide education at associate degree and undergraduate levels (but don't provide education for teaching profession) have also been assigned as teachers. Afterwards, besides faculties of education, people who graduated from faculties of arts and science, and who received graduate education in educational sciences have also been assigned as teachers.

Since 2010-2011 academic year, pedagogic training is began to be provided not via graduate education, but via certificate training. According to the sentence of The Council of Higher Education with the date of 28.01.2010, the students from all faculties and departments, who fulfill necessary conditions in undergraduate period or after graduation, have the right to be assigned as teachers regardless of the

\footnotetext{
${ }^{1}$ Corresponding e-mail: zeynept@sakarya.edu.tr, Sakarya University1 ,Gümüşhane University2

The present study was elaborated from its printed abstract that was represented verbally in the First International Education Programs and Teaching Congress that was held on October 05-08, 2011 at Anadolu University
} 
faculties or departments they are educated in (YÖK, 2010). "Pedagogic Training" that takes part in the process of preparation for teaching profession, could be defined as formation and development required for providing education and teaching. Pedagogical formation simply includes giving pedagogy education to people who already have taken an education in the field and this education is related to how they teach their field (Yildırım and Vural, 2014). Within the framework of pedagogic training, the following courses are provided: Introduction to Teaching Profession, School Experience, Development and Learning, Planning and Assessment in Teaching, Education Technologies and Material Development, Classroom Management, Methods for Special Education 1 and 2, School Experience II, and Guidance. Courses included in pedagogic training are applied as a whole; beginning in the fifth semester along four semesters (2 years) for undergraduates, and two semesters (1 year) for those who completed undergraduate education.

\section{Situation of the Problem}

Several studies have investigated the attitudes of teachers and prospective undergraduate teachers towards teaching profession. However, there are limited studies regarding relationships between various variables and attitudes towards teaching profession among the students and graduates who receive pedagogic training.

In order to meet the requirements for teaching profession, one has to have positive attitudes towards the profession. Carrying out the teaching profession with sympathy is an important factor for being successful in the profession. Therefore, in order to provide opportunities to develop positive attitudes towards teaching profession, and in order to contribute to the efforts for developing and enhancing the pedagogic training, it is important to learn about the attitudes towards teaching profession among the students/graduates who did not prefer teacher education programs, but later took pedagogic training in order to be assigned as teachers.

\section{Aim of the Study}

Aim of the present study is to determine attitudes towards teaching profession among the students who receive pedagogic training in order to be assigned as teachers. Within the framework of this general aim, answers to the following questions have been sought: Do the attitudes towards teaching profession among the students who receive pedagogic training significantly change regarding the variables; (1) gender, (2) level of education (grade or status for graduation), (3) department in which one has took education / graduated from, (4) faculty/school in which one has took education / graduated from.

\section{METHOD}

The research is conducted in screening (descriptive-survey) model. Screening model aims to describe a past or present situation as it is. The sample of the present research is constituted from the students/graduates of Faculty of Science and Arts, Faculty of Fine Arts, Faculty of Theology, School of Physical Education and Sports, and School of Health, who were continuing their pedagogic training programs in Sakarya University Faculty of Education, in the academic year of 2010-2011. The participants were selected via "cluster sampling" method. Frequency distribution of students, taking part in the present study, in terms of variables was shown in Table 1. 
Table 1. Frequency Distribution of Students with regard to Variables

\begin{tabular}{|c|c|c|c|c|}
\hline \multicolumn{2}{|c|}{ Variables } & & $\mathrm{N}$ & $\%$ \\
\hline \multirow{2}{*}{\multicolumn{2}{|c|}{ Gender }} & Female & 497 & 77.2 \\
\hline & & Male & 147 & 22.8 \\
\hline \multirow{3}{*}{\multicolumn{2}{|c|}{ Level of Education }} & $3^{\text {rd }}$ grade & 321 & 49.8 \\
\hline & & $4^{\text {th }}$ grade & 213 & 33.1 \\
\hline & & Graduated & 110 & 17.1 \\
\hline \multirow{6}{*}{\multicolumn{2}{|c|}{ Faculty/High School }} & Faculty of Arts and Sciences & 445 & 69.1 \\
\hline & & Faculty of Theology & 69 & 10.7 \\
\hline & & Faculty of Fine Arts & 25 & 3.9 \\
\hline & & $\begin{array}{l}\text { School of Physical Education and } \\
\text { Sports }\end{array}$ & 30 & 4.7 \\
\hline & & Health High School & 30 & 4.7 \\
\hline & & School of State Conservatory & 45 & 7.0 \\
\hline \multirow{9}{*}{\multicolumn{2}{|c|}{$\begin{array}{l}\text { Faculty of Arts } \\
\text { and Sciences }\end{array}$}} & History & 84 & 13.0 \\
\hline & & Geography & 27 & 4.2 \\
\hline & & Sociology & 96 & 14.9 \\
\hline & & Philosophy & 17 & 2.6 \\
\hline & & Turkish Philology & 88 & 13.7 \\
\hline & & German Philology & 34 & 5.3 \\
\hline & & Chemistry & 17 & 2.6 \\
\hline & & Biology & 23 & 3.6 \\
\hline & & Mathematics & 59 & 9.2 \\
\hline \multirow{11}{*}{ Departments } & Faculty of & Basic Islamic Sciences & 37 & 5.7 \\
\hline & Theology & Islamic History and Arts & 32 & 5.0 \\
\hline & Faculty of Fine & & 13 & 2.0 \\
\hline & Arts & Traditional Turkish Handicrafts & 12 & 1.9 \\
\hline & $\begin{array}{l}\text { School of } \\
\text { Physical }\end{array}$ & Recreation & 18 & 2.8 \\
\hline & $\begin{array}{l}\text { Education and } \\
\text { Sports }\end{array}$ & Sport Management & 12 & 1.9 \\
\hline & Health High & Midwifery & 12 & 1.9 \\
\hline & School & Nursing & 18 & 2.8 \\
\hline & & Basic Sciences & 12 & 1.9 \\
\hline & school of State & Turkish Folk Dances & 12 & 1.9 \\
\hline & & Turkish Music & 21 & 3.3 \\
\hline
\end{tabular}

\section{Material}

In data collection, "Inventory for Attitudes towards Teaching Profession" (IATTP) that was developed by Üstüner (2006) was utilized. The inventory, which revealed single factor on five-point likert type scale, included 34 items, out of which 24 were positive and 10 were negative. Regarding the construct validity of the inventory, it is implied that the first factor which was constituted of 34 items had factor loadings ranging from .74 and .41 and explained $30 \%$ of the variance. The criterion validity of the inventory was .89 , its reliability coefficient was .72, and the internal consistency coefficient (Cronbach Alpha) was .93. Demographic informations of the students/graduates who received pedagogic training were obtained from 4 questions that were on the same form.

\section{Data Analyses}

For data analyses, SPSS 13.0 Statistical Package Program was used. The items of "Inventory for Attitudes towards Teaching Profession" were scored as (5) "Totally Agree", (4) "Mostly Agree", (3) "Somewhat Agree", (2) "Partially Agree", and (1) "Disagree". Negative items were reversed prior to the analyses. Analyses revealed the following descriptive information; 1.00-1.80: Disagree, 1.81-2.60: Partially Agree, 2.61-3.40: Somewhat Agree, 3.41-4.20: Mostly Agree, 4.21-5.00: Totally agree. T-test and analyses of 
variance were performed in order to investigate whether the scores differed according to the variables. 0.05 was accepted as the significance level in the research.

\section{FINDINGS}

$\mathrm{T}$ test results of pedagogical formation certification program students' attitudes towards teaching profession related to gender variable was presented in Table 2.

Table 2. T test results of students' attitudes towards teaching profession related to gender variable

\begin{tabular}{ccccccc}
\hline Gender & $\mathbf{N}$ & $\bar{x}$ & sd & df & t & P \\
\hline Female & 497 & 4.12 & 0.55 & 642 & 0.66 & 0.51 \\
Male & 147 & 4.09 & 0.58 & & & \\
\hline
\end{tabular}

As Table 2 shows that students' attitudes towards teaching profession do not change in accordance with gender variable $\left[\mathrm{t}_{(642)}=0.66, \mathrm{p}>.05\right]$.

Analysis of variance results of pedagogical formation certification program students' attitudes towards teaching profession in the sense of level of education can be seen in Table 3.

Table 3. Analysis of Variance Results of Students' Attitudes towards Teaching Profession and Level of Education

\begin{tabular}{|c|c|c|c|c|c|c|c|c|c|}
\hline $\begin{array}{l}\text { Level of } \\
\text { Education }\end{array}$ & $\mathbf{N}$ & $\operatorname{Mean}(\bar{x})$ & sd & & $\begin{array}{l}\text { Sum of } \\
\text { Squares }\end{array}$ & df & $\begin{array}{l}\text { Mean } \\
\text { Square. }\end{array}$ & $\mathbf{F}$ & $\mathbf{p}$ \\
\hline $3^{\text {rd }}$ Grade & 321 & 4.110 & .558 & $\begin{array}{l}\text { Between } \\
\text { Group }\end{array}$ & .225 & 2 & .113 & & \\
\hline \multirow[t]{2}{*}{$4^{\text {th }}$ Grade } & 213 & 4.112 & .611 & & & & & & \\
\hline & & & & $\begin{array}{l}\text { Within } \\
\text { Group }\end{array}$ & 203.875 & 641 & .318 & .354 & .702 \\
\hline Graduated & 110 & 4.161 & .478 & & & & & & \\
\hline Total & 644 & 4.119 & .563 & Total & 204.098 & 643 & & & \\
\hline
\end{tabular}

As Table 3 shows that students' attitudes towards teaching profession do not differ in terms of level of education $\left[\mathrm{F}_{(2-641)}=0.354, \mathrm{p}>.05\right]$.

Table 4 represents the variance analysis of students' attitudes to teaching profession in relation to faculty or high school variable.

Table 4. Variance Analysis of Students' Attitudes to Teaching Profession in relation to Faculty/ High School Variable

\begin{tabular}{|c|c|c|c|c|c|c|c|c|c|}
\hline $\begin{array}{l}\text { Faculty/ High } \\
\text { School }\end{array}$ & $\mathbf{N}$ & $\begin{array}{l}\text { Mean } \\
(\bar{x})\end{array}$ & sd & & $\begin{array}{l}\text { Sum of } \\
\text { Squares }\end{array}$ & df & $\begin{array}{l}\text { Mean } \\
\text { Square }\end{array}$ & $\mathbf{F}$ & $\mathbf{p}$ \\
\hline $\begin{array}{l}\text { Faculty of Arts and } \\
\text { Sciences }\end{array}$ & 445 & 4.082 & .583 & Between & & & & \multirow{4}{*}{4.774} & \multirow{4}{*}{.000} \\
\hline Faculty of Theology & 69 & 4.152 & .445 & Group & 7.360 & 5 & 1.472 & & \\
\hline Faculty of Fine Arts & 25 & 3.950 & .599 & & & & & & \\
\hline $\begin{array}{l}\text { School of Physical } \\
\text { Education and } \\
\text { Sports }\end{array}$ & 30 & 4.449 & .545 & $\begin{array}{l}\text { Within } \\
\text { Group }\end{array}$ & 196.738 & 638 & .308 & & \\
\hline
\end{tabular}




\begin{tabular}{lllllll}
\hline Health High School & 30 & 4.056 & .512 & & & \\
$\begin{array}{l}\text { School of State } \\
\begin{array}{l}\text { Conservatory } \\
\text { Total }\end{array}\end{array}$ & 45 & 4.358 & .399 & & & \\
\hline
\end{tabular}

As Table 4 represents that students' attitudes toward teaching profession change significantly in accordance with faculty or high school which they are studying at or they were graduated from. $[\mathrm{F}(5-638)=$ $4.774, \mathrm{p}<.05]$. In order to find the source of the difference, scheffe test was conducted and according to findings, there is a significant difference between students from School of physical education and sports and from Faculty of Arts and Sciences for the benefit of students from School of physical education and sports.

Kruskal Wallis H- Test results of students' attitudes towards teaching profession in relation to departments of the Faculty of Arts and Sciences can be seen in Table 5.

Table 5. Kruskal Wallis H- Test Results of Students' Attitudes towards Teaching Profession in relation to Departments of the Faculty of Arts and Sciences

\begin{tabular}{|c|c|c|c|c|c|c|}
\hline Department & $\mathbf{N}$ & $\begin{array}{l}\text { Mean } \\
\text { ranks }\end{array}$ & df & $x^{2}$ & $\mathbf{P}$ & Significance \\
\hline History & 84 & 211.85 & & & & History-Turkish \\
\hline Geography & 27 & 231.00 & & & & Philology \\
\hline Sociology & 96 & 198.21 & & & & Chemistry-Turkish \\
\hline Philosophy & 17 & 201.26 & & & & Philology \\
\hline Turkish Philology & 88 & 267.88 & 8 & 18.689 & .017 & Biology-Turkish \\
\hline German Philology & 34 & 222.31 & & & & Philology \\
\hline Chemistry & 17 & 194.0 & & & & Sociology-Turkish \\
\hline Biology & 23 & 188.4 & & & & Philology \\
\hline Mathematics & 59 & 236.2 & & & & \\
\hline
\end{tabular}

As is seen in Table 5, attitudes of students towards teaching profession shows a significant difference in the way of departments of Faculty of Arts and Sciences [ $\left.X^{2}=18.689, p<.05\right]$. So as to find the source of the difference, Mann Whitney U-test was conducted by regarding binary combination of the groups. There is a significant difference between Turkish Philology students/graduates and History, Chemistry, Biology and Sociology students/graduates in the interest of Turkish Philology students.

Table 6 shows T test results of students' attitudes towards teaching profession in relation to departments of the Faculty of Theology.

Table 6. T Test Results of Students' Attitudes towards Teaching Profession in relation to Departments of the Faculty of Theology

\begin{tabular}{lllllll}
\hline Departments & $\mathbf{N}$ & $\bar{x}$ & sd & Df & t & P \\
\hline Basic Islamic Sciences & 37 & 4.104 & .481 & 67 & .960 & .347 \\
Islamic History and Arts & 32 & 4.206 & .400 & & .960 & \\
\hline
\end{tabular}

According to Table 6, students' attitudes do not differ in terms of departments of Faculty of Theology $\left[\mathrm{t}_{(67)}=0.960, \mathrm{p}>.05\right]$.

Table 7 shows Mann Whitney U test results of students' attitudes towards teaching profession in accordance with departments of Faculty of Fine Arts. 
Table 7. Mann Whitney U Test Results of Students' Attitudes towards Teaching Profession in accordance with Departments of Faculty of Fine Arts

\begin{tabular}{lccccc}
\hline Departments & N & Mean Ranks & Rank Sum & U & p \\
\hline Painting & 13 & 11.38 & 148.00 & & \\
$\begin{array}{l}\text { Traditional Turkish } \\
\text { Handicrafts }\end{array}$ & 12 & 14.75 & 177.00 & 57.000 & .253 \\
\hline
\end{tabular}

Table 7 indicates that students' attitudes do not differ significantly with regard to departments of Faculty of Fine Arts [U=57.000, $\mathrm{p}>$.05].

Mann Whitney U test results of pedagogical formation students' attitudes toward teaching profession as regards departments of School of Physical Education and Sports can be seen in Table 8.

Table 8. Mann Whitney U Test Results of Pedagogical Formation Students' Attitudes towards Teaching Profession as regards Departments of School of Physical Education and Sports

\begin{tabular}{lccccc}
\hline Departments & N & $\begin{array}{l}\text { Mean } \\
\text { Ranks }\end{array}$ & Rank Sum & U & p \\
\hline Recreation & 18 & 16.33 & 294.00 & 93.000 & .525 \\
Sport Management & 12 & 14.23 & 174.00 & \\
\hline
\end{tabular}

According to Table 8, there is no significant difference between departments of School of Physical Education and Sports in terms of students' attitudes towards teaching profession [U=93.000, $p>.05]$.

Mann Whitney U test results of students' attitudes with regards to departments of Health School can be seen in Table 9.

Table 9. Mann Whitney U Test Results of Students' Attitudes in terms of Departments of Health School

\begin{tabular}{lccccc}
\hline Departments & N & Mean Ranks & Rank Sum & U & p \\
\hline Midwifery & 12 & 11.29 & 135.50 & \multirow{2}{*}{57.500} & .032 \\
Nursing & 18 & 18.31 & 329.50 & & \\
\hline
\end{tabular}

Table 9 represents that there is a significant difference between departments of Health High School in the sense of students' attitudes [ $\mathrm{U}=57.500, \mathrm{p}<.05]$. When mean ranks considered nursing students' attitudes towards teaching profession are significantly higher than those of midwifery students.

Table 10. Kruskal Wallis H Test Results of Students' Attitudes with regard to Departments of School of State Conservatory

\begin{tabular}{lccccc}
\hline \multicolumn{1}{c}{ Departments } & $\mathbf{N}$ & $\begin{array}{l}\text { Mean } \\
\text { Ranks }\end{array}$ & $\mathbf{d f}$ & $\mathbf{X}^{2}$ & $\mathbf{P}$ \\
\hline $\begin{array}{l}\text { Basic Sciences } \\
\text { Turkish Folk }\end{array}$ & 12 & 22.00 & & & \\
$\begin{array}{l}\text { Dances } \\
\text { Turkish Music }\end{array}$ & 12 & 22.58 & 2 & .162 & .922 \\
\hline
\end{tabular}

As Table 10 shows that students' attitudes do not change significantly in terms of departments of School of State Conservatory $\left[\mathrm{X}^{2}=0.162, \mathrm{p}>.05\right]$. 


\section{RESULT, DISCUSSION, AND SUGGESTIONS}

The present study examines the attitudes of students, taking pedagogical formation, towards teaching profession in relation to gender, level of education, department, faculty/ high school variables. Findings of the study indicates that there is no significant difference between students' attitudes towards teaching profession in terms of gender variable. Some researches support this finding (Demirel and Akkoyunlu, 2010; Bulut, 2009; Başbay, Ünver and Bümen, 2009; Okçu and Çelik, 2009; Gömleksiz, Oral and Bulut, 2006; Bulut and Doğar, 2006; Şimşek, 2005; Yüksel, 2004; Çapa and Çil, 2000) whereas results contradict with some other studies (Eraslan and Çakıcı, 2011; Aksoy, 2010; Keser, Bayır and Numanoğlu, 2009; Çapri and Çelikkaleli, 2008; Seferoğlu, 2004). There is no significant difference between students' attitudes towards teaching profession in the sense of students' level of education ( $3^{\text {rd }}$ and $4^{\text {th }}$ grade or graduated). Similarly Çapa and Çil (2000) found no significant difference between $3^{\text {rd }}$ and $4^{\text {th }}$ grade students' attitudes towards teaching profession. Furthermore, Eraslan and Çakıcı (2011) found no significant difference between pedagogical formation students' attitudes towards teaching profession in terms of level of education ( $3^{\text {rd }}$ grade or graduated). With regard to faculty or high school variable students' attitudes show a significant difference between School of Physical Education and Sports and Faculty of Arts and Sciences. The attitudes of students from School of Physical Education and Sports are significantly higher than those from Faculty of Arts and Sciences. School of Physical Education and Sports include education courses related to physical education as compared to Faculty of Arts and Sciences so that students' attitudes towards teaching profession maybe higher in School of Physical Education and Sports. Moreover, students who take pedagogical formation training answers questions on the scale mostly by "mostly agree" option. Researches support this finding (Bulut, 2009; Şimşek, 2005; Demirel and Akkoyunlu, 2010; Başbay, Ünver and Bümen, 2009). In terms of departments there is no significant difference between departments of Faculty of Theology, Fine Arts, School of Physical Education and Sports, State Conservatory while there is a significant difference between departments of Faculty of Arts and Sciences and Health High School. Turkish Philology students from Faculty of Arts and Sciences shows higher attitudes towards teaching profession than History, Chemistry, Biology and Sociology students. Similarly, nursing students from Health High School represents significant higher attitudes towards teaching profession than Midwifery students. Findings of studies related to department show differences (Aksoy, 2010; Çapa and Çil, 2000; Demircioğlu and Özdemir, 2014; Saracaloğlu et al., 2004). Order of priority for departments changes every year in the sense of teacher assignment so that attitudes of students from those departments can be different towards teaching profession and this can explain contradictory findings in the literature with regard to department variable. Further studies that compare pedagogical formation students' attitudes towards teaching profession in terms of faculty or high school variables are necessary. In addition, quantitative and qualitative studies which investigate why students from different faculties and high schools except for Education faculties take pedagogical formation in order to be a teacher should be carried out. Discussions about the necessity and quality of pedagogical formation frequently come to the fore. Researches show that training teachers with pedagogical formation creates some problems (Gül, Bakan and Ünal, 2014; Yıldırım and Vural, 2014). Teaching profession should be qualified, regarded as a specialization profession, and pedagogical formation certification programs should be improved accordingly.

\section{REFERENCES}

Aksoy, M. E., (2010). Öğretmen adaylarının öğretmenlik mesleğine ilişkin tutumları. Sosyal Bilimler Araştırma Dergisi, 2, 197-212.

Başbay, M., Ünver, G. \& Bümen, N. T. (2009). Ortaöğretim alan öğretmenliği tezsiz yüksek lisans öğrencilerinin öğretmenlik mesleğine yönelik tutumları: Boylamsal bir çalışma. Kuram ve Uygulamada Eğitim Yönetimi, 15 (59), 345-366.

Bulut, İ. (2009). Öğretmen adaylarının öğretmenlik mesleğine ilişkin tutumlarının değerlendirilmesi (Dicle ve Frrat üniversitesi örneği). Dicle Üniversitesi Ziya Gökalp Eğitim Fakültesi Dergisi, 14, 13-24.

Bulut, H. \& Doğar, Ç. (2006). Öğretmen adaylarının öğretmenlik mesleğine karşı tutumlarının incelenmesi. Erzincan Eğitim Fakültesi Dergisi, 8 (1), 13-27. 
Celep, C. (2010). Meslek olarak öğretmenlik. C. Celep (Ed.), Ĕ̆itim bilimine giriş içinde (s. 45-74). (3. Baskı). Ankara: Anı Yayıncilık.

Çapa, Y. \& Çil, N. (2000). Öğretmen adaylarının öğretmenlik mesleğine yönelik tutumlarının farklı değişkenler açısından incelenmesi. Hacettepe Üniversitesi Eğitim Fakültesi Dergisi, 18, 69-73.

Çapri, B. \& Çelikkaleli, Ö. (2008). Öğretmen adaylarının öğretmenliğe ilişkin tutum ve mesleki yeterlik inançlarının cinsiyet, program ve fakültelerine göre incelenmesi. İnönü Üniversitesi Eğitim Fakültesi Dergisi, 9 (15), 33-53.

Çelik, K. (2010). Bir meslek olarak öğretmenlik. A. Tanrı̈ğen \& R. Sarpkaya (Eds.), Ĕ̆itim bilimine giriş içinde (s.235-265). (2. Baskı). Ankara: Anı Yayıncılık.

Demircioğlu, E. \& Özdemir, M. (2014). Fen ve edebiyat fakültesi öğrencilerinin öğretmenlik mesleğine yönelik tutumlarının çeşitli değişkenlere göre incelenmesi. Mersin Üniversitesi Ĕ̆gitim Fakültesi Dergisi, 10 (3), 110-122.

Demirel, M. \& Akkoyunlu, B. (2010). Öğretmen adaylarının öğretmenlik mesleğine ilişkin öz-yeterlik inançlar ve tutumları. Uluslararası Öğretmen Yetiştirme Politikaları ve Sorunları Sempozyumu II, 16-18 Mayıs, Hacettepe Üniversitesi, Beytepe-ANKARA.

Eraslan, L. \& Çakıcı, D. (2011). Pedagojik formasyon programı öğrencilerinin öğretmenlik mesleğine yönelik tutumları, Kastamonu Eğitim Dergisi, 19 (2), 427-438.

Gömleksiz, M. N., Oral, B. \& Bulut, İ. (2006). Ortaöğretime nitelikli öğretmen yetiştirmede tezsiz yüksek lisans uygulaması. Orta Öğretimde Yeniden Yapılanma Sempozyumu 20-22 Aralık 2004 Bildiriler Kitabı içinde (s. 545-551), Ankara: MEB Talim Terbiye Kurulu Başkanlığı.

Gül, İ., Bakan, S. \& Ünal, A. (2014). Pedagojik formasyon uygulamasında karşılaşılan sorunlar (Ondokuzmayıs Üniversitesi örneği). 9. Ulusal Eğitim Yönetimi Kongresi, 8-10 Mayıs, Siirt.

Helvacı, M. A. (2007). Öğretmenlik mesleğinin özellikleri. N. Saylan (Ed.), Ĕ̆itim bilimine giriş içinde (s. 313332). Ankara: Anı Yayıncilı.

Keser, H., Bayır, Ş. \& Numanoğlu, G. (2009). Öğretmen adaylarının öğretmenlik mesleğine yönelik tutumları. Uluslararası 5. Balkan Eğitim ve Bilim Kongresi, 1-3 Ekim 2009, Edirne.

Okçu, V. \& Çelik, H. Ç. (2009). Öğretmen adaylarının KPSS'ye ilişkin görüşlerinin öğretmenlik mesleğine yönelik tutumlarına etkisi. I. Uluslararası Türkiye Eğitim Araştırmaları Kongresi, 1-3 Mayıs 2009, Çanakkale.

Saracaloğlu, A. S., Bozkurt, N., Serin, O. \& Serin, U. (2004). Öğretmen adaylarının mesleğe yönelik tutumlarını etkileyen faktörler. Çă̆gaş Eğitim Dergisi, 311, 16-27.

Seferoğlu, S. S. (2004). Öğretmen yeterlikleri ve mesleki gelişim. Bilim ve Aklın Aydınlı̆̆ında Ĕ̆itim, 58, 40-45.

Şimşek, H. (2005). Ortaöğretim alan öğretmenliği tezsiz yüksek lisans programına devam eden öğrencilerin öğretmenlik mesleğine yönelik tutumları. Yüzüncü Yıl Üniversitesi Elektronik Ĕ̆itim Fakültesi Dergisi, 2(1), http://efdergi.yyu.edu.tr, 07/10/2010 tarihinde alındı.

Üstüner, M. (2006), Öğretmenlik mesleğine yönelik tutum ölçeğinin geçerlik ve güvenirlik çalışması, Kuram ve Uygulamada Eğitim Yönetimi, 45, 109-127.

Yıldırım, İ. \& Vural, Ö. F. (2014). Türkiye'de öğretmen yetiştirme ve pedagojik formasyon sorunu. Journal of Teacher Education and Educators, 3 (1), 73-90.

Yükseköğretim Kurulu, (YÖK). (2010). 28.01.2010 tarih ve 03317 sayılı yazısı.

Yüksel, S. (2004). Tezsiz yüksek lisans programının öğrencilerin öğretmenlik mesleğine ilişkin tutumlarına etkisi. Uludă̆ Üniversitesi Eğitim Fakültesi Dergisi, 17(2), 355-379 